\title{
Public Service media ANd Public Communication: CONCEPT, CONTEXT AND EXPERIENCES
}

\author{
Fernando Oliveira Paulino, Liziane Guazina \& Madalena Oliveira
}

\begin{abstract}
Unlike the commercial sector because, among other aspects, it does not have a profitable objective, the public sector of communication has been defined according to a principle of universality and of equal access of citizens to media products. Notwithstanding this basic ground, which is more or less common to the public service broadcasting systems from most origins, the denomination of public service broadcasting - consistent with a European tradition - is not an unequivocal correlate of the concept of public communication - more in tune with an American, at least South-American, tradition. Focused on the experiences of Portugal and Brazil, this paper develops a comparative approach that aims to understand the political, social, and cultural framework of the public media activity in these two countries. Based on an analysis of legal documents that support the development of this activity, the paper is meant to discuss the sector in the broader context of Portuguese and Brazilian communication policies. On the other hand, while not ignoring the aspects - such as funding and independence issues - that have made public service broadcasting and public communication a field of permanent debate, this article also aims to identify and discuss the challenges faced by concessionary companies.
\end{abstract}

Keywords

Public service; policies on communication; public communication; RTP; EBC

\section{To BE PUblic, OF ALL, FOR ALL}

As a noun, the word public refers to the idea of a set or group of people, usually with common sensitivities or interests, which is why it can be used as a synonym for audience or listeners. Therefore, it is a word as old as the aggregation of people due to coincident motivations and joint practices. Having an economic connotation (in the field of art and spectacle, for example), the common name public has, above all, a cultural meaning. It expresses the organisation of people according to practices and lifestyles. It is, for this reason, essentially a plural concept that does not correspond anymore to the idea of masses that had proliferated at the beginning of the media age.

As an adjective, the qualifying word public means something that belongs to everyone, that is done in front of everyone, that is open or accessible to all. Unlike private, the term public assumes in some way the idea of sharing, well denoted in expressions such as public space, public sphere, public opinion, or public consultation. As an extreme opposite to what would be intimate, private, or personal, public refers to what is projected for the collective, although the adjective public does not have the same strength of communion that exists in what is defined as communitarian. 
To be public means being potentially of all. In other words, it means admitting the participation and involvement of all, insofar as what is said to be public may directly or indirectly affect the collective interest and the collective life. Hence, being public also means being potentially for all, having a general impact. There is indeed an inclusive meaning in the public being that, in a democratic context, also has an implicit suggestion of equality among those to whom the public item is addressed.

In spite of being related to different traditions, as is demonstrated in the following sections, the concepts of public service and public communication collect from the word public a principle of universality that is inspired by this generic meaning of being of all and for all. The meaning is in part the same suggested by the promotion of public education, public health, or public security, that is, to guarantee a kind of common minimum to all citizens.

Although the term may also designate what is relative or what belongs to the government of a country - an expression which, moreover, has certainly inspired many debates questioning the autonomy of the public service media and public communication in relation to official information - the promotion of public media is generally presented as an alternative to the commercial segmentation of audiences. The public character is therefore derived from the fact that these media companies are guaranteed by the state: that is to say, they belong to everyone in terms of ownership and they are intended to be pluralistic in terms of content diffusion, to be for all. Ostensibly generous in purpose, the public media are, however, as pointed out below, a complex and ambiguous reality in terms of communication policies.

\section{Public Service media in Portugal: Concept and tradition}

In general terms, the principle of public service concerns the satisfaction of the needs of the population and is implied in the Constitution of the Portuguese Republic as a result of a commitment between the rights of the citizens and the duties of the state. As Silvio Correia Santos explains in a book on public service media, "the notion of public service is present in modern society under a multiplicity of meanings" (Santos, 2013, p. 3). It is, in effect, the result of the redefinition of the functions and role of the state in guaranteeing the political principles of freedom, equality, and fraternity, emanating from the French Revolution. If, initially, a less interventive state had been sought in the defence of the principle of public service - for education, health, security, telecommunications, and information - there is a certain return to state responsibility, which in some European countries, such as Portugal, gave rise to what was conventionally called the welfare state.

Public service in the field of media is also explicitly provided for in the Portuguese Constitution. Paragraph 5 of Article 38, on freedom of the press and media, establishes that "the State ensures the existence and operation of a public radio and television service". In the following paragraph, it is further clarified that

the structure and functioning of the public sector media must safeguard its independence from the Government, the Administration and other public authorities, as well as ensuring the expression and confrontation of the various currents of opinion. (Constitution, Article 38, paragraph 6) 
The Law on Television and On-Demand Audiovisual Services (Law no. 27/2007, of July 30, updated in some aspects by later decrees), establishes in Article 5 that "the State ensures the existence and operation of a public service television", which "may integrate audiovisual services on demand or other audiovisual services necessary for the fulfilment of its purposes". Likewise, the Law on Radio, in its most recent formulation published at the end of 2010 (Law no. 54/2010, of December 24), establishes, also in Article 5, that "the State ensures the existence and operation of a public service radio under concession".

Although in Portugal radio and television have always been linked to the initiative of the State, the idea of public service for audiovisual media is more recent. The foundation in 1935 of the Emissora Nacional' and in 1956 of RTP², both state enterprises, was still far from this public service consciousness that did not exist in the original wording of the 1976 Constitution, the first after the April Revolution. At that time it was established only that television could not be an object of private property. The role of the state in the introduction of radio and television in Portugal was as an almost exclusive agent in the field of radio broadcasting and of a monopoly in the field of television. The history of these means is not, therefore, originally a history of public service in the fullness of the expression. Only the third revision of the current Constitution, in 1989, removed from the constitutional text "the obstacles to the entry of private operators into television activity" (Sousa \& Santos, 2005, p. 69) and introduced the obligation of the state to ensure the existence and operation of public service radio and television, setting it in the terms currently in force in the Portuguese sovereign law.

The end of the 1980's was, moreover, vigorous from the point of view of media in Portugal. In addition to regularising the radio sector, which put an end to the so-called pirate radios or free radios, by licensing 314 local frequencies, new newspapers appeared (such as the weekly $O$ Independente, created in 1988) and the country was preparing for the opening of television broadcasting to private initiatives (which was inaugurated with the premiere of SIC in October 1992). Therefore, in part, the proliferation of new media open to private initiates is more or less responsible for the idea that the state should play a regulatory role by guaranteeing alternative or differentiated service.

Currently, public service media are provided under a concession agreement signed between the Portuguese state and RTP - Rádio e Televisão de Portugal, S.A., a limited liability company with public capital, dedicated to the production and distribution of audiovisual and multimedia content. Setting out the principles of public service and the obligations of the concessionary company, the Concession Agreement of the Public Service of Radio and Television was signed in its most recent version in March 2015, repealing the previous documents of 1999 and 2008 and assigning the concession for a term of 16 years.

Central to understanding what is meant by public service media in Portugal, the Concession Agreement states that public service is guided by a set of objectives (Clause 5)

\footnotetext{
' This is the name of the first national radio broadcaster.

${ }^{2}$ RTP means Portuguese Radio and Television.
} 
that include the promotion of "humanism, freedom, civility, citizenship, social solidarity, and pluralist democratic debate", the defence of the Portuguese language and culture, and the production of "independent, rigorous, pluralistic and in-depth information constituting a reference of credibility and trust for diverse audiences". Regarding responsibilities, the document details a broad list of specific obligations aimed at implementing the principles conventionally recognised in public service. It is suggested that the concessionary company should guarantee plurality (of content), universality (for all audiences), impartiality, autonomy and independence, and promotion of the Portuguese language and culture (in particular through an approach to the Portuguese diaspora and support to national production), as well as media literacy.

Responding to the requirements established in the contract, RTP in 2016 is a group consisting of a wide variety of channels and editorial projects. In the field of radio there are eight main broadcasters: Antena 1 (the most general-interest), Antena 2 (dedicated to more cultural programming), Antena 3 (targeted toward the young public), RDP Madeira Antena 1 and Antena 3 and RDP Açores (directed towards the autonomous regions of Madeira and the Açores), RDP África (directed toward the Portuguese-speaking African countries), and RDP International (directed toward the Portuguese diaspora in the world). In addition to these services, in the radio sector, the RTP group also promotes six other products that work exclusively online: Antena 1 Lusitânia, Antena 1 Vida, Antena 1 Fado, Antena 2 Ópera, Antena 1 Memória, and Zig Zag Radio, a project dedicated to programming aimed at children and adolescents. In the television domain, the concessionaire has eight channels: RTP 1 (the general-interest channel), RTP 2 (the erudite or cultural channel), RTP 3 (a 24-hour news channel), RTP Memória (which broadcasts old programmes), RTP África (likewise for radio, addressed to Portuguese-speaking African countries), RTP International (dedicated to the Portuguese emigrant population), and RTP Madeira and RTP Açores (special channels for the Portuguese archipelagos).

Although RTP funding has in part been borne by the state budget in the form of compensatory indemnities, RTP's income for all of its services is currently based on the contribution to the audiovisual sector paid by all signatories of an electricity contract ( $€ 2,81$ per month) and on its own commercial revenues (namely advertising, which is allowed on RTP 1 only). In a sense, it can be said that RTP's financing model is based on a kind of compulsory crowdfunding, because, on the assumption that they are electricity customers, all residents in Portugal are called upon to contribute to the concessionaire's budget.

\section{Public COMmunication in Brazil: CONCEPT AND TRAdition}

Being born of private interests, Brazilian public broadcasting was established on the initiative of different national governments, namely those of an authoritarian nature - either in the Vargas period or in the military civil dictatorship from the 1960 s onwards. Radio and television broadcasters linked to different state agencies for the dissemination of information met the objective of informing the public about the activities of the state and its government. 
Historically, the Brazilian public broadcasting service suffered from limitations of a political and structural nature, as its consolidation depended more on the alignment of casuistic interests of professional politicians, with or without a mandate, than it did on a public communication project. In addition, the proximity relations between business groups owning media and professional politicians is still one of the factors limiting the consolidation of the Brazilian public broadcasting as a system with political autonomy and financial independence.

In spite of the fact that, in 1988, the Brazilian Constitution established the complementarity of the public, state, and private systems in Article 223, the public broadcasting system was regulated and delimited organically only 20 years later, in 2008 , based on Law 11.652 of April 7, 2008, which created the Empresa Brasil de Comunicação [Brazil Communications Company] (EBC) and defined the principles of the public system. These principles refer, directly or indirectly, to the idea of promoting citizenship and equality of access to information. They result from the context of claiming the rights to communication and information and the achievement of human and social rights in the Brazilian Constitution. They must therefore be understood within the scope of the achievement of social rights arising from the mobilisation of civil society in the periods of redemocratisation and post-redemocratisation.

The promotion of access to information through a plurality of sources, for example, is defined in Article 2 of the law, as is the production of content for educational, cultural, and informational purposes and a prohibition against discrimination on the basis of politics, partisanship, philosophy, ethnicity, gender, or sexual choice. The idea of promoting citizenship is also present in the objectives of the public broadcasting system, especially those listed in Article 3 of the same law:

II - to develop the critical awareness of the citizen, through educational, artistic, cultural, informative, scientific and citizenship promoter programmes; and III - to promote the construction of citizenship, the consolidation of democracy and participation in society, guaranteeing the right to information, free expression of thought, creation and communication

The commitment to the idea of plurality (internal and external), to the diversity of sources in journalistic coverage, to the selection of themes focused on the citizens' demands and interests, and to ethics and non-partisanship is therefore explicitly stated in the law that created the Brazilian public communication system. As claimed by different social groups, these principles denote a certain convergence of priority agendas for the mobilisation of sectors of society that sought to guarantee political conditions to approve, in the National Congress, the law proposed by former President Luiz Inácio Lula da Silva. This commitment was also expressed in the creation of a Curator's Council for the EBC, which brought together civil society representatives to discuss and evaluate the programming of public broadcasters in accordance with the principles established by law, and the maintenance of an Ombudsman's Office that responds to internal and external requests and inquiries. 
The Brazilian public communications system is currently composed of two television stations (TV Brasil is the most relevant in this context), eight radio stations, an Internet news agency, and a radio agency. In addition, the system also includes a network of public radio and television stations operated in partnership between the EBC and federal universities (or other institutions). According to a determination of the Ministry of Communications in 2014, four TV stations and 11 radio stations are under shared management ${ }^{3}$. Other broadcasters linked to state structures may also rebroadcast EBC TV and radio programming, as well as send information material to EBC channels. According to the Management Report for 2014, EBC employs 2,572 professionals: the majority of them graduated $(1,124)$ and bonded in an effective way to the company by public competition $(2,055)^{4}$.

The structure of the EBC channels came largely from public companies such as Empresa Brasileira de Notícias - (EBN) and Empresa Brasileira de Comunicação (Radiobrás), created in the 1970 s under the auspices of authoritarian governments and merged in 1988 under the name Radiobrás. Both companies adopted a communication model of a more state than public character, in addition to forms of management closer to the patrimonialism historically characteristic of the Brazilian state.

The notion that the public broadcasting system constitutes a public communication system that must obey principles referring, directly or indirectly, to the idea of promoting citizenship did not occur, however, in an extemporaneous or historical way. It is linked to the collective construction about the need for public communication generated within the mobilisations of the area's academic community and of unions and social movements over the last 30 years of democracy. It began to take shape, even if in an incipient and precarious way, in the last years of Radiobrás, during the first term of Lula's government.

Despite the divergence of approaches to public communication, it can be said that the debate over the right to information and communication, the democratisation of the media, and the defence of community radio stations occurred before and during the 1990s, and the effervescence of the claims for more participation and inclusion of different groups that compose Brazilian society in the public broadcasting system in the 2000 s was an essential factor for the formulation of parameters of what would be a public communication aligned with the promotion of citizenship and diversity.

Although there has always been concern in Brazil about the dissemination of state information (in certain historical periods in the form of propaganda), in the full sense of the term public, public communication is finally understood as different from government communication or political communication. The debate on the pertinence and relevance of the public sector - which admits various funding sources ${ }^{5}$ - tends to undermine this distinction, but, according to the law, the principles and objectives of public broadcasting services

\footnotetext{
${ }_{3}$ See http://www.ebc.com.br/institucional/sobre-a-ebc/canais-ebc-e-parceiros/2014/03/canais-ebcparceiros

${ }_{4}^{4}$ See http://www.ebc.com.br/institucional/sites/_institucional/files/atoms/files/relatorio_de_gestao_ebc_-_2014_o.pdf

${ }_{5}^{5}$ According to Article 11 of Law 11.652, the resources of the EBC come from budget allocations, a Contribution for the Promotion of Public Broadcasting, the provision of services, donations, institutional publicity, and distribution of legal publicity of entities of the federal administration, etc.
} 
operated by the executive power or assigned to entities of its indirect administration are not confusable with the promotion of governments. According to the Article 2 of Law 11.652, the principles related to the provision of public broadcasting services include the "promotion of access to information through the plurality of sources of content production and distribution", as well as "production and programming with educational, artistic, cultural, scientific and informative purposes" and "promoting national culture, stimulating regional production and independent production". The law also says that the public broadcasting service presumes "autonomy in relation to the Federal Government to define production, programming and distribution of content in the public broadcasting system" and "participation of civil society in controlling the application of the principles of the public broadcasting system, respecting the plurality of Brazilian society".

\section{PoRTUGAL-BraZiL: COMPARING THE “ALMOST INCOMPARABLE”}

According to common sense, the act of comparing is deeply linked to the identification of similarities (and eventually differences). Looking at the experience of public service media in Portugal and the experience of public communication in Brazil is an exercise that does not hide this attempt to identify correspondences. The reasons that suggest a comparative examination in this case are, however, less based on the expectation of finding coincidences and more related to the supposed affective proximity between two countries that speak the same language. In an attempt to "theorize about the role of context" (Mancini \& Hallin, 2012, p. 515), the approach proposed in this article takes into account that, by a matter of dimension (historical, geographic, and administrative), Portugal and Brazil would be "almost incomparable".

In Portugal, the history of broadcasting bears, as we said before, the visible mark of the hand of the state. After the creation of the Portuguese Society of Amateurs of Wireless Telephony in 1922, the Emissora National (EN), a project of the Estado Novo (especially of António Ferro and António Oliveira Salazar), appeared as the first national radio station in 1935. The introduction of TV in Portugal and the inauguration in 1957 of the regular broadcasts of RTP - which would operate in a monopoly until the 1990 - is also due to the Estado Novo, especially to Marcello Caetano. In Brazil, the history of radio broadcasting began with the performance of private operators - radio by the initiative of Edgar Roquette Pinto, who inaugurated, in 1923, Rádio Sociedade; television thanks to the journalist and businessman Assis Chateaubriand, who founded, in 1950, the first TV channel in the country, TV Tupi in São Paulo.

It is possible that the different origins of radio and TV in the two countries are not particularly significant in terms of public service and public communication. Nevertheless, it is curious that the public service system is, at least apparently, more stable where the state was from the very beginning the owner of audiovisual media.

Notwithstanding this historical difference, and although the two countries coincide in what the instrumentalisation of media for the purposes of political propaganda meant in periods of censorship, Brazil seems to be more explicit in defending, even 
today, means of communication that have the purpose of giving visibility to the action of the instances of power. There are, in fact, in Brazil, media enhanced by public entities (such as TV Senado, which has vast programing and has UHF channels in practically every state in the country) to transmit events and information related to official activities. Perhaps the only equivalent of this sector in Portugal is the Canal Parlamento, which, according to Assembly Resolution 37/2007, of August 20, aims to provide "the signal of the internal video network of the Assembly of the Republic for the purposes of its distribution through public and private cable television networks" (Article 2). The distinction made in Brazil between state media and public media, which does not exist in Portugal, does not seem to be enough to legitimise public communication as a system diverse from one that seeks to ensure institutional communication.

Also, the financing system for public media is very different in Portugal and Brazil. If in Brazil we admit different sources of income, as we pointed out in the previous section, in Portugal all of the work carried out by the public company, RTP, is financed by the Audiovisual Contribution and the advertising distributed exclusively in RTP 1.

From the point of view of the organisational structure, both the Portuguese system and the Brazilian system, based respectively on RTP and EBC, are based on the existence of an Administration Board and a Fiscal Council; until mid-2016, both had an advisory structure made up of members external to the company. RTP maintains the Opinion Council and the Independent General Council. The government of Michel Temer, however, removed the EBC Curator's Council. The two companies also maintain a system of answering the demands and suggestions presented by the audiences, RTP through the figures of the Ombudsman for the Listeners and the Ombudsman for the TV viewers, and the EBC through an Ombudsman Office, which is in fact much more administrative than the Portuguese service (Oliveira \& Paulino, 2012; Paulino \& Oliveira, 2014).

It is true that the so-called public service media has existed in Portugal since the 1990 , which means that it precedes Brazil's public communication system only by about a decade. However, given that the Portuguese media landscape is less fractured than the Brazilian one (for reasons of a smaller geographic dimension), the radio and television stations of the RTP group are now a sector of relative stability. On the contrary, for essentially political reasons, the media of the EBC group have become what some Brazilian media called "the new obsession of Temer" 6 .

In fact, after a period of great instability, under Dilma Rousseff's government, with regard to what a public communication company should be, the dilemmas of legitimacy, financial independence, and political autonomy in relation to executive power returned, resulting in questions concerning the experience of $E B C$ and the public system as a whole. While RTP benefitted from a period of some social serenity regarding the idea of public service, in June 2016 the EBC began a critical period of vulnerability aggravated by the appointment of Michel Temer as President of the Republic in August of the same year.

Eight years after the creation of Empresa Brasil de Comunicação and the definition, by law, of the principles of public citizen communication, the abrupt change in the maximum

\footnotetext{
${ }^{6}$ See, for instance, http://www.cartacapital.com.br/revista/918/ebc-a-nova-obsessao-de-temer
} 
position of the executive leadership caused a strong impact on the destiny of the Brazilian public communication system, leaving the future of public broadcasting uncertain. While still in his provisional period, the new president removed the EBC's director, who had been appointed few days earlier and was guaranteed a four-year term by law. A new director was immediately appointed, but his appointment was put on hold by an injunction granted by the Minister of the Supreme Court at the request of the outgoing director. After the confirmation of Michel Temer as President of the Republic due to the impeachment of Dilma Rousseff, a Provisional Measure redefined the EBC organisation chart, extinguished the Curator's Council, and changed the composition of the Administration Board by including new representatives of the federal government.

\section{OLD AND NEW CHALLENGES FOR THE PUBLIC SECTOR OF COMMUNICATION}

Public broadcasting services (radio and TV) are often presented as crucial for the development of democratic societies, as they are guided by an idea that aims to promote access to information, diversity, and cultural identity, as well as mechanisms that promote social inclusion and the participation of citizens in public debate. Contrary to the idea that public media service is a thing of the past, David Hendy argues that "public broadcasting today is more important than ever" (Hendy, 2013, p. 4). In his book Public Service Broadcasting - which Hendy says is not about the BBC or about regulatory policies - the author suggests that public service is, above all, an ethos.

It is therefore commonly said, among those who defend this sector, that public radio and TV broadcasters have the potential to provide an effective complement to commercial services by seeking to satisfy the information needs and interests to which the market cannot give an answer. Traditionally, public service broadcasters in pioneer countries (such as England, Germany, and Italy) have been operated as protected monopolies. Such a perspective has ceased to be a reality in the last three decades, with the entry of competitors from the private sector. Today a "double system" is in force, based on the balance between public service and commercial broadcasting organisations. According to Toby Mendel (2011, p. vii), in places like Spain, public broadcasters are losing audiences. But in the UK and the Nordic nations, there are public service broadcasters who find strong support among citizens and are therefore able to hold large slices of the audience.

In Portugal, the main public service television and radio stations, RTP 1 and Antena 1 , respectively, compete for audiences in values very close to those of the private signal operators. It is not in this field, therefore, that the main challenges of the public broadcasting system are located, which only in the case of more marginal projects - such as RTP 2 and Antena 2 - register residual audiences. Contrary to what happens in Brazil, public service radio and television channels in Portugal are relatively well integrated in the media landscape, being part of the mainstream media.

The apparent political calmness of the theme in the Portuguese context does not, however, definitively erase the critical points experienced by this sector. Although perhaps to a lesser extent than the crisis in which the EBC project plunged during 2016, in 
Portugal the public service media have also gone through delicate periods of public discussion. In March 2002, for example, with the election of Durão Barroso's Social Democrat government, the issue became sensitive because, confronted with the company's serious economic situation at the time, the Executive "replaced - in a controversial way - the Administration, admitted the possibility of reducing the number of channels and the number of personnel and put the scenario of the company extinction on the table" (Pinto, 2005, p. 12).

Since then, although more moderately, the public service media sector is on the regular agenda in both public and academic circles. Discussions are focused much more on television than on radio: as Sílvio Correia Santos points out, "the discussion about PSM is an unbalanced discussion" because "we do not talk about public radio, or the Internet, but about television" (Santos, 2013, p. 1). In addition to scientific production on the subject, it is around television that the public service debate usually reverberates? Making the debate more equitable and revalorising the radio domain would therefore be one of the challenges that, at least from an academic point of view, would be important in terms of communication policies for the public sector.

It would also be a challenge for the Portuguese public service media to resolve the question of public service legitimation. This is, at various levels, a wound that is always open. Because of the funding model or because of the autonomy and independence of the operators in respect to political power, public service media in Portugal is systematically confronted with the imputation of unfair competition to the private sector and its inclusion in the realm of political ideology. In referring to television, Eduardo Cintra Torres points out that "the ideological crystallisation of the public television service becomes transformed into ideas that cannot even be questioned, as if they were religious beliefs" (Torres, 2011, p. 81).

Responsibilities for the production and distribution of alternative content (which are outside the scope of audience-oriented programming), the need to alert operators to concerns about media literacy (in particular through quality programming for children and educational programmes for all audiences) and constant technological updating are some of the challenges that continue to prevail in the debate on public service media in Portugal. If these are more or less recurrent issues, there also seems to be a question of the overall positioning of the public service, particularly with regard to the operators' strategy in Brazil, where international channels have poorly penetrated ${ }^{8}$.

With the introduction of the Ombudsman for the Listener and the Ombudsman for the TV Viewer in 2006, the Portuguese public service met one of the recommendations set forth by researchers at the Communication and Society Research Centre, who in 2003

\footnotetext{
7 In the context of Portuguese scientific production, there are several works dedicated to television and public service. In this area, besides the group of researchers of the Communication and Society Research Centre who published Televisão e Cidadania, in 2005 (already mentioned in this text), Eduardo Cintra Torres, author of Televisão e Serviço Público (Torres, 2011) and Francisco Rui Cádima, who has published some articles in the perspective of television (Cádima, 2012) can be mentioned as references in this approach concerning mainly television.

${ }^{8}$ This is one of the dimensions in discussion in the doctoral thesis that the former RTP journalist Carlos Fino is preparing at the University of Minho (co-sponsored by the University of Brasília).
} 
suggested that "public service television should find out and develop ways of public participation in the regular monitoring of their work" (Pinto, 2005, p. 135). However, the alliance with research centres for the development of applied studies remains a challenge, a project in which EBC, in Brazil, presented itself with more conviction thanks to specific agreements with some universities, namely with the University of Brasília. On the other hand, despite their dedication to Portuguese-speaking international communities, it is still a challenge for public service operators to approach local communities, at a time when regional production centres are gradually losing their importance.

In the Brazilian case, the main threat to public communication is investors of governmental authorities, who wish to exercise control over broadcasters and increase their political capital by using them as their spokesmen. In doing so, they end up undermining the independence of public broadcasters and the quality of news and programming through government control practices.

In Brazil, in principle, broadcasting licenses are publicly owned and the Constitution ensures the complementarity of public, state, and private systems. In practice, the model is too hybrid. Radio and television broadcasters need concessions, granted and renewed by the National Congress, supposedly in the public interest. But the search for the audience and the existence of private interests of some groups push radio and TV broadcasters out of the plurality and diversity characteristics of public broadcasting.

On the other hand, because they arose mostly from government initiatives, noncommercial broadcasters are mostly linked to the executive branch apparatus, and coexist with a centralised administrative structure, marked by performance without editorial and financial independence, and are not subject to mechanisms of transparency and accountability. Economic barriers make it difficult and even impossible to maintain their programming with the necessary innovation and quality of production required by contemporary broadcasting.

However, Brazil and other Latin American countries, with recent decades' rise or reassertion of governments of parties historically related to groups that defend the democratization of communication, have at least begun a process of reorganisation of educational, cultural, or state channels, bringing them closer to the precepts that characterise them as a public service. Recent attempts to implement changes - some timid and others more comprehensive - in normative frameworks, such as the creation of Empresa Brasil de Comunicação (EBC), provide some clues about the process of transformation and maturation of the country to establish agreements to offer an independent and democratic public broadcasting service.

The EBC has tried to assert itself as an option to the current broadcasting model, as it intends to be effectively public. However, as a result of the associations regarding what is public, in Brazil, since its inception, it has run a risk of legitimation. After all, the public sector is often seen as inefficient, bureaucratic, corrupt, and inoperative, or as something that can be squandered because "it would not belong to anyone". Moreover, the Brazilian model tries to define and separate what is public from the government and the state. EBC has tried to distance itself from the mere diffusion of government acts, or 
government itself, and to have the public's interest in information and entertainment as its main parameter.

Even as it seeks to guarantee independence, the fact that its sustainability depends on public funds faces resistance. The law that created the EBC provided that its financing should be constituted, in part, by the Contribution for the Promotion of Public Radio Communication with funds from the Telecommunications Inspection Fund (Fistel). Although there was no provision for a new tax, Brazilian telephone companies moved a Direct Action of Unconstitutionality in 2009 to question the Fund, and until now only a portion of this resource was actually made available.

Even so, it is necessary to have a regulation to define how and where this resource will be used, as the EBC gains capillarity in the country through contracts of partnerships with educational broadcasters, on which there is a bigger interference of the state governments and a lack of investment in content and infrastructure. And these broadcasters would also have the right to use a part of that contribution to strengthen their roles at the local and national levels. Thus, without being able to effectively count on this contribution, EBC continues to be dependent on National Treasury resources and barred from advertising the goods and services of private companies, despite advertising public agencies and receiving cultural support for some productions.

Another difficulty in legitimising the public broadcasting service in Brazil is its alleged low audience, one of the reasons used by the new government to justify its downsizing. Moreover, private companies advertise a number of issues in the media that address the high cost of public broadcasting and the small number of viewers, listeners, and readers reached. This approach questions the capacity of the public service to establish, renew, and strengthen links with the audience: that is, with Brazilian citizens themselves. This relationship tends to be cyclically redefined in its meanings from social, political, cultural, and economic scenarios that are increasingly dynamic and mutant.

It should also be noted that recent worldwide changes that have taken place in the audiovisual landscape, with the development of digital technologies, paid-for platforms, and online communication services, have also affected the traditional double broadcasting system and editorial competition (in terms of quality and diversity of content), making it necessary for public and private broadcasters to diversify their operations and face new distribution platforms. With a wide range of options available to users, public broadcasters face almost continuous difficulties in justifying their existence and, in particular, their income and use of public resources.

At the same time, contemporary digital platforms can provide an opportunity for broadcasters to approach their audiences. Toby Mendel (2011, pp. 19-20) suggests that public media can build a space of credibility and reliability with the use of new digital platforms and can play a bridge-building role in order to fragment the media. The author suggests using them to increase the accessibility of their services and to offer new options, including interactive media services, to reach all audiences, particularly the youth.

In short, the idea is that public radio and TV broadcasters should make extensive and varied use of new technologies in order to facilitate and extend services rendered in 
fulfilling their public service competencies. This has been reinforced in international resolutions, such as European Union Directives, drawing attention to the need of preserving the "special social competence" of broadcasters in the new digital environment, while still allowing them the flexibility to take advantage of new technological developments.

Independently, however, of the potential use of digital technologies, the EBC remains at a standstill with regard to journalistic activity. From the institutional point of view, there has been an effort in recent years (at least in the official reference documents) to link news production to objectives that represent the interests of citizens. In practice, however, public journalism did not differ much from what is offered by private broadcasters, whether from the point of view of content or from the point of view of concept. This is the case, for example, of the journalism content of the radio stations of EBC Nacional AM, Nacional FM, and Rádio Mec. The short time, the use of brief news as a preponderant format, the lack of contextualisation of the information, and the predominance of official sources are some of the characteristics that indicate journalism produced in similarity to the model of the commercial experience of radio journalism in Brazil (Guazina \& Paulino, 2015).

From the management point of view, internal changes were made after the incorporation of the former Radiobrás in EBC, including the renewal of professionals through public competition and the redefinition of parameters of professional performance. However, it is still possible to observe in journalistic programming the need for a concept of the role of journalism in all of EBC's activities and its effective contribution in fulfilling the promises related to citizenship aimed at the principles of the company.

If the current stage of public service broadcasting was no longer encouraging, now even more can be feared for the future. In terms of public policies, there is no sign that the Brazilian federal government will promote changes to reduce the asymmetries of power (in terms of budget, equipment, audience, etc.) between public and private broadcasters; on the contrary, there is not even a recognition that public communication is important for Brazilian society and represents a conquest of citizenship.

\section{Culture ANd identity of Portuguese expression}

In an article published in 1997, Dave Atkinson explains that the first reason for public service broadcasting was technical (Atkinson, 1997, p. 19). Today, however, in the complex media system developed in the meantime, the reasons that may still support an idea of public service for media are essentially cultural. In addition to the need to ensure an array of services and products that are not in line with economic imperatives, the public service media are expected to contribute to the social and cultural development of the countries they represent9. Notwithstanding the different experiences of Portugal and Brazil, whose media systems are, after all, so different, at least one reason justifies

\footnotetext{
9 This is the particular emphasis of the project "Communication Policies, Public Broadcasting and Citizenship: Subsidies for the Sociocultural Development of Portugal and Brazil," developed by the Communication and Society Research Centre of the University of Minho and by the Faculty of Communication of the University of Brasília, funded by FCT and Capes.
} 
the comparative approach that was tested in this article: defending a cultural function of approximation between the two countries. In addition to all of the motives of principle attributed to the defence of public service media, the promotion of cultural practices of Portuguese expression and the strengthening of intercultural ties, together with the need to promote a more committed citizenship, are today some of the main arguments that underpin the insistence on a public communication system. Finally, public service media is currently being asked to safeguard the national identity(ies) of the dangers that globalisation can represent to cultural diversity.

\section{BibLIOGRAPHIC REFERENCES}

Atkinson, D. (1997). Overview of a crisis. In D. Atkinson, \& M. Raboy (Eds.), Public service broadcasting: the challenges of the twenty-first century (pp. 19-30). Paris: Unesco.

Cádima, F. R. (2012). A relegitimação do serviço público de televisão em Portugal no contexto de hiperfragmentação da oferta. Anuário Internacional de Comunicação Lusófona, 25-33.

Guazina, L. S. \& Paulino, F. O. (Eds.) (2015). Relatório final do monitoramento EBC-UnB. Brasília: Universidade de Brasília.

Hendy, D. (2013). Public service broadcasting. London: Palgrave Macmillan.

Mancini, P. \& Hallin, D. (2012). Some caveats about comparative research in media studies. In H. A. Semetko, \& M. Scammell (Eds.), Handbook of political communication (pp. 509-517). Thousand Oaks: Sage Publications.

Mendel, T. (2011). Serviço público de radiodifusão: um estudo de direito comparado. Brasília: Unesco.

Oliveira, M. \& Paulino, F. O. (2012). O ombudsman nos meios públicos de comunicação em Portugal e no Brasil: da promessa de uma ética participada aos desafios cotidianos. Anuário Internacional de Comunicação Lusófona, 75-84.

Paulino, F. O. \& Oliveira, M. (2014). Ombudsmen in the Brazilian and Portuguese media: a reflection on the activities developed between 1989 and 2013. Brazilian Journalism Research, 58-75.

Pinto, M. (2005). Serviço público - uma perspetiva. In M. Pinto (Ed.), Televisão e cidadania: contributos para o debate sobre o serviço público (pp. 11-21). Porto: Campo das Letras.

Santos, S. C. (2013). Os média de serviço público. Covilhã: Livros LabCom.

Sousa, H. \& Santos, L. A. (2005). RTP e serviço público: um percurso de inultrapassável dependência e contradição. In M. Pinto (Ed.), Televisão e cidadania: contributos para o debate sobre serviço público (pp. 61-80). Famalicão: Campo das Letras.

Torres, E. C. (2011). A televisão e o serviço público. Lisboa: FFMS/Relógio d’Água.

\section{OTHER REFERENCES}

DOU/1988, de 5 de outubro, República Federativa Brasileira [Constituição da República Federativa Brasileira]

Lei Constitucional 1/2005, de 12 de agosto, República Portuguesa [Constituição da República Portuguesa]. 
Lei $n^{\circ}$ 27/2007, de 30 de julho, República Portuguesa.

Lei $n^{\circ}$ 54/2010, de 24 de dezembro, República Portuguesa.

Lei 11.652, de 7 de abril de 2008, República Federativa Brasileira.

Resolução da Assembleia da República n³7/2007, de 20 de agosto, República Portuguesa.

\section{BIOGRAPHICAL NOTES}

Fernando Oliveira Paulino is Professor and Director of the Faculty of Communication at the University of Brasília; he is researcher at the Laboratory of Communication Policies of the same university of Director of International Relations of ALAIC, the LatinAmerican Association of Researchers on Communication.

Email: paulino@unb.br

Faculdade de Comunicação

Universidade de Brasília

Campus Universitário Darcy Ribeiro

Asa Norte

Brasília-DF, 70910-900, Brasil

Liziane Guazina is Professor and Vice-Director of the Faculty of Communication at the University of Brasília, where she coordinates the Nucleus of Studies on Media and Politics. She is member of the Research Group on Culture, Media and Politics and works on media and politics, political journalism and public communication.

Email: guazina@unb.br

Faculdade de Comunicação

Universidade de Brasília

Campus Universitário Darcy Ribeiro

Asa Norte

Brasília - DF, 70910-900, Brasil

Madalena Oliveira is Associate Professor at the Institute of Social Sciences and integrated researcher of the Communication and Society Research Centre at the University of Minho; she is vice-president of Sopcom, the Portuguese Association of Communication Sciences and works on radio and sound, journalism and languages and communication policies.

Email: madalena.oliveira@ics.uminho.pt

Instituto de Ciências Sociais

Universidade do Minho

Campus de Gualtar

4710-057 Braga, Portugal 
* Submitted: 15-03-2016

* Accepted: 15-04-2016 